\title{
Identification of enterobacteria in free-living nonhuman primates in an urban park in the northern region of the state of Paraná, Brazil
}

\section{Identificação de enterobactérias em primatas não-humanos de vida livre em um parque urbano na região norte do estado do Paraná, Brasil}

\author{
Melissa Marchi Zaniolo ${ }^{1}$; Aliny Fernanda de Oliveira ${ }^{1}$; Rafael dos Santos \\ Tramontin ${ }^{1}$; Isabela Carvalho dos Santos ${ }^{1}$; Robson Michel Delai ${ }^{1}$; Ulisses de Pádua \\ Pereira $^{2}$; Evandra Maria Voltarelli Pachaly ${ }^{3}$; José Ricardo Pachaly ${ }^{4}$; Lisiane de \\ Almeida Martins ${ }^{4}$; Daniela Dib Gonçalves ${ }^{4 *}$
}

\begin{abstract}
Populations of nonhuman primates are often considered to be a link in the chain of emerging infectious diseases, as they are reservoirs for different zoonotic pathogens. The objective of this study was to identify the presence of bacteria from the family Enterobacteriaceae in free-living nonhuman primates. The research was carried out in an urban park located in a city in the northern region of the State of Paraná, Brazil. The animals were captured in Tomahawk-type traps and chemically restrained, being oral and rectal samples collected with sterile swabs. For bacterial isolation, the samples were seeded on MacConkey agar plates and grown under anaerobic conditions. The subsequent identification was conducted using a commercial biochemical kit. Sixteen primates identified as black-capuchin-monkeys (Sapajus nigritus) were captured. Seven different enterobacterial species were identified from the oral cavity swabs: six Escherichia coli (42.9\%), three Kluyvera species (21.40\%), one Serratia rubidaea (7.14\%), one Enterobacter aerogenes (7.14\%), one Enterobacter cloacae (7.14\%), one Hafnia alvei (7.14\%), and one Erwinia herbicola (7.14\%). Seven different species were identified from the rectal swabs: six Escherichia coli (40\%), three Kluyvera species (20\%), two Enterobacter aerogenes (13.32\%), one Erwinia herbicola (6.67\%), one Serratia rubidaea (6.67\%), one Pragia fontium (6.67\%), and one Edwardsiella tarda (6.67\%). The results indicate that the isolated bacteria belong mainly to the human microbiota and had crossed the interspecific barrier, contaminating the nonhuman primates.

Key words: Gram-negative bactéria. Family Enterobacteriaceae. Monkeys. Microorganisms. Sapajus nigritus.
\end{abstract}

\footnotetext{
1 Discentes, Programa de Pós-Graduação em Ciência Animal com Ênfase em Produtos Bioativos, Universidade Paranaense, UNIPAR, Umuarama, PR, Brasil. E-mail: melissaz.vet@gmail.com; alinyfer@hotmail.com; rafael_tramontin@hotmail.com; isabela_carvalhoxd@hotmail.com; rmdelai@gmail.com

2 Prof. Dr., Programa de Pós-Graduação em Ciência Animal, Universidade Estadual de Londrina, UEL, Londrina, PR, Brasil. E-mail: upaduapereira@gmail.com

3 Médica Veterinária, Prefeitura Municipal de Maringá; Instituto Brasileiro de Especialidades em Medicina Veterinária, ESPECIALVET, Maringá, Paraná, Brasil. E-mail: emvoltarelli@hotmail.com

4 Profs., Programa de Pós-Graduação em Ciência Animal com Ênfase em Produtos Bioativos, UNIPAR, Umuarama, PR, Brasil. E-mail: pachaly@uol.com.br; lisiane.almeida.martins@gmail.com; danieladib@unipar.br

* Author for correspondence
}

Received: Nov. 21, 2017 - Approved: Apr. 02, 2018 


\section{Resumo}

As populações de primatas não humanos frequentemente são consideradas um elo na cadeia de doenças infecciosas emergentes, por constituírem reservatórios que propiciam o surgimento de diferentes patógenos zoonóticos. O objetivo deste trabalho foi identificar a presença de bactérias da família Enterobacteriaceae em primatas não humanos de vida livre. O estudo foi realizado em um parque urbano localizado em uma cidade da região norte do Estado do Paraná. Os animais foram capturados em armadilhas do tipo Tomahawk e submetidos a contenção farmacológica para colheita de amostras da microbiota oral e retal com zaragatoas estéreis. Para o isolamento bacteriano as amostras foram semeadas pela técnica de esgotamento em placas contendo ágar MacConkey, com posterior identificação por testes bioquímicos utilizando kit comercial. Foram capturados 16 primatas não humanos identificados como Sapajus nigritus (macaco-prego). Na cavidade oral foi possível identificar sete diferentes espécies de bactérias, sendo seis $(42,9 \%)$ Escherichia coli, três espécies de Kluyvera $(21,40 \%)$, uma $(7,14 \%)$ Serratia rubidae, uma $(7,14 \%)$ Enterobacter aerogenes, uma $(7,14 \%)$ Enterobacter cloacae, uma $(7,14)$ Hafnia alvei e uma (7,14\%) Erwinia herbicola. No reto foi possível identificar sete diferentes espécies de bactérias, sendo seis (40\%) Escherichia coli, três espécies de Kluyvera (20\%), duas (13,32\%) Enterobacter aerogenes, uma (6,67\%) Erwinia herbicola, uma (6,67\%) Serratia rubidae, uma (6,67\%) Pragla fotiun e uma $(6,67 \%)$ Edwardsiella tarda. Os resultados indicam que as bactérias isoladas são pertencentes principalmente à microbiota humana, e estão ultrapassando a barreira interespecífica $\mathrm{e}$ contaminando os primatas.

Palavras-chave: Bactérias Gram-negativas. Família Enterobacteriaceae. Macacos. Microrganismos. Sapajus nigritus.

\section{Introduction}

Species belonging to the order Primates have remarkable behavioral, phenotypic, and genotypic variation, and this includes the endocrine and reproductive aspects. Black-capuchin-monkeys are endemic neotropical primates in the Brazilian Atlantic Forest. They are distributed from the right bank of the Doce River, in Minas Gerais, to the north of Rio Grande do Sul, being bounded on the west by the Paraná River (VILANOVA et al., 2005).

Taxonomically, "black-capuchin" is a denomination that includes two genera, Cebus and Sapajus (LYNCH-ALFARO et al., 2012). Species with a characteristic physical robustness, presence of hair tufts on the top of the head, and a brown or dark gray coat with the ventral parts tending to be more reddish in color were allocated to the genus Sapajus, except for the populations of the southern region of Brazil, which are black in coat color and may represent a taxonomic group distinct from their northern counterparts (Sapajus libidinosus). Males and females are between 42 and $56 \mathrm{~cm}$ and 42 and
$48 \mathrm{~cm}$ in length, respectively, with a tail of up to 56 $\mathrm{cm}$. The weight of the animals can vary between 2.6 and $4.8 \mathrm{~kg}$ (LYNCH-ALFARO et al., 2012).

These animals generally have an omnivorous diet and great behavioral plasticity, giving them the capacity to subsist in anthropic environments (BERNARDO; GALETTI 2004; LUDWIG et al., 2006; ROCHA, 2000).

An important effect observed in the fragmentation of habitats is the high density of primates present in small forest fragments (BERNARDO; GALETTI, 2004; CHIARELLO, 2003; JARDIM, 2005; VAN BELLE, 2006). In the long term, these fragments become insufficient to house and maintain viable populations, compromising the survival of the animals in concert with the deleterious effects of inbreeding and the impossibility of dispersion to other fragments.

Populations of primates are often considered to be a link in the chain of emerging infectious diseases, as they are reservoirs for different zoonotic pathogens (CORTE et al., 2005; DASZAK et al., 2004; 
GARCIA et al., 2005). In public health, the concern over nonhuman primates is not only the risk of them transmitting zoonotic infectious diseases to humans, but also the lesions caused by their bites. Because they are animals that are considered intelligent and have quick reflexes and great physical strength, their attacks can be severe (SATTERFIELD; VOSS, 1987). In general, the oral cavity and teeth of monkeys constitute a hyperseptic medium, cultivating highly polymorphic saprophytic and pathogenic microorganisms, as well as enzymes and biological degradation products that are often toxic (DORTU, 1978). Such microorganisms form the natural microbiota and have great importance for the normal functioning of the organs of these animals (MURRAY et al., 2014). These microorganisms are a consequence of the animals' diets, which ranges from varied fruits to small rodents and insects, or of their constant habit of putting their dirty and possibly fecal-contaminated hands in their mouth (ASPIS et al., 2003).

As these animals have direct contact with humans, they can transfer Gram-positive and Gramnegative bacteria through their bite and feces. Fecal materials are dispersed in the environment and found in places where there are wild or domestic animals, human waste, or any surfaces with fecal contamination. Bacteria can survive for a long time in moist soil, water, feces, food, and organic matter surfaces, and therefore, contamination can occur by different means (NUNES et al., 2010).

Of the bacteria found in nonhuman primates, the most important are the enterobacteria belonging to the family Enterobacteriaceae, which are ubiquitous microorganisms found in soil, water, and vegetation in any part of the world. These microorganisms are part of the normal microbiota of most animals, including humans. They cause a variety of diseases in humans, including one third of all cases of bacteremia, more than $70 \%$ of urinary tract infections, and many intestinal infections. Some microorganisms such as Salmonella enterica serotype Typhi, Shigella species, and Yersinia pestis are always associated with human diseases, whereas others such as Escherichia coli, Klebsiella pneumoniae, and Proteus mirabilis are commensals (i.e., members of the normal microbiota) that can cause opportunistic infections (BRITO et al., 2014; CRUZ et al., 2017; LOUREIRO et al., 1985).

Data from population surveys and census of primate populations provide information on the socioecological differences of the species and are an important tool in determining conservation priorities (GANZHORN et al., 1996), supporting debates, and developing species conservation strategies.

The main justification for the conservation or biomedical scientific research of nonhuman primates is their considerable anatomical, physiological, endocrine, and behavioral similarity to humans. In addition to these similarities, they also share the susceptibility to various infectious agents capable to cross interspecific barriers (JOSLIN, 2003). For this reason, the objective of this study was to identify Enterobacteriaceae bacteria in nonhuman primates living in an urban park in the northern region of the State of Paraná, Brazil. The study was carried out in partnership with a research group that had been formed to manage and control this population of nonhuman primates following reports of several occasions of home invasion and food theft committed by these animals, as well as cases of park visitors being bitten that were reported to local health services.

\section{Materials and Methods}

\section{Place of study}

This study was carried out in a municipal urban park located in a city in the northern region of the State of Paraná, Brazil, from 2014 to 2015. The park has an area of 47.3 hectares of semi-deciduous seasonal forest, and wild, exotic, and synanthropic animals. The most common species is the freeliving Sapajus nigritus (MARÓSTICA, 2010). 
Animal capture and sample collection

The primates were captured in Tomahawk-type traps distributed inside the park and checked every day. The baits were composed of elements of the animals' usual diet, such as fruits and eggs. Once trapped, the animals were captured with a hand net and anesthetized by a single-dose intramuscular injection of the association called "ZAX-50", prepared with a combination of tiletamine and zolazepam (Zoletil-50®, Virbac do Brasil, São Paulo, Brazil), xylazine (Rompun ${ }^{\circledR}$, Bayer S.A., São Paulo, Brazil), and atropine (Atropina 1\%, Farmagricola S.A., Mairiporã, Brazil) in the same syringe or dart. The doses of each item were calculated by interspecific allometric scaling', based on the usual indication for domestic dogs, according to the indication of Pachaly et al. (2011) for Cercopithecinae nonhuman primates.

The animals were submitted to physical examination and therefore the collection of oral and rectal samples was conducted using sterile swabs containing Aimes medium with activated charcoal (Transystem $^{\mathrm{TM}}$, Copan Italia, Brescia, Italy). For rectal sampling, the swabs were introduced into the rectal ampulla of each primate, compressing it with rotating movements. For oral sampling, the swabs were inserted into the oral cavity, swabbing gums and tongue with circular and rotating movements.

The collected samples materials were refrigerated and sent to the Laboratory of Preventive Veterinary Medicine and Public Health of the Post-Graduate Program in Animal Science with Emphasis on Bioactive Products of the Universidade Paranaense (UNIPAR, Umuarama, Brazil) for bacterial isolation and identification.

\section{Diagnostic tests}

\section{Bacterial isolation}

The swabs containing rectal and oral samples were placed in tubes containing $3.0 \mathrm{~mL}$ of brain heart infusion (BHI) medium and incubated in an oven for $24 \mathrm{~h}$ at $37^{\circ} \mathrm{C}$. After this period, the samples were seeded on MacConkey agar plates and on base agar containing 5\% defibrinated sheep blood, and incubated in an oven for $24 \mathrm{~h}$ at $37^{\circ} \mathrm{C}$ under anaerobic condition (QUINN et al., 2005).

The isolated bacterial colonies were inoculated into $3.0 \mathrm{~mL}$ of BHI medium and incubated in an oven for $24 \mathrm{~h}$ at $37^{\circ} \mathrm{C}$. After this period, the cells were centrifuged for $15 \mathrm{~min}$ and the supernatant was discarded. The cells were resuspended in $2.0 \mathrm{~mL}$ of BHI with $10 \%$ glycerol, homogenized, aliquoted into two containers, and stored at $-20^{\circ} \mathrm{C}$.

\section{Biochemical identification of isolated bacteria}

The biochemical identification of bacteria belonging to family Enterobacteriaceae was carried out using a specific enterobacterial identification kit (NewProv ${ }^{\circledR}$, Paraná, Brazil), according to the manufacturer's recommendations. The samples were subjected to the following tests, recommended by Quinn et al. (2005): L-triphosphane deamination; gas production from glucose; hydrogen sulfide production; lysine and/or ornithine decarboxylation; motility; indole; and rhamnose, citrate, glucose, fructose, and lactose fermentation.

\section{Results}

Fourteen male (87.50\%) and two female (12.50\%) nonhuman primates identified as Sapajus nigritus were captured, all of them young adults weighing between 1.7 and $3.8 \mathrm{~kg}$.

Two swab samples (one oral and one rectal) were collected from each animal, totaling 32 samples of which enterobacteria were found on 11 oral and 11 rectal swabs (31.82\%). Seven types of bacteria were isolated in five samples (31.82\%) (Table 1). 
Table 1. Identification of species of the family Enterobacteriaceae in oral cavity and rectal swab samples from 16 Sapajus nigritus individuals captured in an urban park in a city in the northern region of the State of Paraná, Brazil, 2017.

\begin{tabular}{|c|c|c|}
\hline Sample & $\begin{array}{l}\text { Identified Species } \\
\text { Oral Cavity }\end{array}$ & $\begin{array}{l}\text { Identified Species } \\
\text { Rectum }\end{array}$ \\
\hline 1 & Kluyvera species & $\begin{array}{l}\text { Serratia rubidaea } \\
\text { Enterobacter aerogenes }\end{array}$ \\
\hline 2 & Enterobacter aerogenes & $\begin{array}{l}\text { Edwardsiella tarda } \\
\text { Kluyvera species }\end{array}$ \\
\hline 3 & $\begin{array}{l}\text { Hafnia alvei } \\
\text { Escherichia coli }\end{array}$ & $\begin{array}{l}\text { Kluyvera species } \\
\text { Enterobacter aerogenes }\end{array}$ \\
\hline 4 & Escherichia coli & Escherichia coli \\
\hline 5 & $\begin{array}{l}\text { Serratia rubidaea } \\
\text { Escherichia coli }\end{array}$ & $\begin{array}{l}\text { Pragia fontium } \\
\text { Escherichia coli }\end{array}$ \\
\hline 6 & Escherichia coli & Escherichia coli \\
\hline 7 & $\begin{array}{l}\text { Erwinia herbicola } \\
\text { Enterobacter cloacae }\end{array}$ & Erwinia herbicola \\
\hline 8 & Kluyvera species & Kluyvera species \\
\hline 9 & Kluyvera species & Escherichia coli \\
\hline 10 & Escherichia coli & Escherichia coli \\
\hline 11 & Escherichia coli & Escherichia coli \\
\hline
\end{tabular}

Seven different species of enterobacteria were identified in the oral cavity swabs: six Escherichia coli (42.9\%), three Kluyvera species (21.40\%), one Serratia rubidaea (7.14\%), one Enterobacter aerogenes (7.14\%), one Enterobacter cloacae (7.14\%), one Hafnia alvei (7.14\%), and one Erwinia herbicola $(7.14 \%)$.

Seven different species of bacteria were identified in the rectal swabs: six Escherichia coli $(40 \%)$, three Kluyvera species (20\%), two Enterobacter aerogenes (13.32\%), one Erwinia herbicola (6.67\%), one Serratia rubidae (6.67\%), one Pragia fontium (6.67\%), and one Edwardsiella tarda (6.67\%).

The same microorganisms was isolated in both areas in seven individuals (63.63\%) (Table 1).

\section{Discussion}

There are not many studies related to the investigation of enterobacteria in free-living nonhuman primates. For this reason, the findings in this study have epidemiological relevance in obtaining data on the socioecological differences of the species, which are important for determining conservation priorities (GANZHORN et al., 1996), supporting debates and developing of species conservation strategies.

The bacteria of the Enterobacteriaceae family are grouped into three categories: main pathogens, causing enteric and systemic diseases; opportunistic pathogens, occasionally causing clinical diseases outside the alimentary tract; and nonpathogens (QUINN et al., 2005). Epidemiological studies on different species of wild animals, such as raccoons, collared peccaries, ocelots (GOMES et al., 2011; LIMA et al., 2012; SILVA et al., 2016), and nonhuman primates mostly living in captivity 
(RAMALHO et al., 2015; VALE; AGUIAR, 2012), were carried out to investigate the occurrence of enterobacteria, considering their possibility of compromising human, animal, and environmental health, i.e., One Health. Thus, it is important to study the microbiota of the captured monkeys, mainly because of the contact they have with park visitors.

This is the first study of this kind carried out on free-living Sapajus nigritus living in an urban park of the northern region of Paraná. The idea of investigating enterobacteria in these animals arose from the possibility of their direct interaction (or indirect contact via the environment) with park visitors, who include public cleaning workers, people who go on walks or take part in zipline or capoeira activities, musicians, elementary and high school students on environment class trips, among others. The possible interaction with these animals, or with the environment where they live, could cause health disorders in humans as well as in other animal species.

This research identified $41.38 \%$ of the isolated bacteria as being Escherichia coli. A similar result was found by Pinheiro and Rodrigues (2014) in free-living black-striped capuchin monkeys (Cebus libidinosus) living at a zoobotanical park in Teresina (PI), where Escherichia coli was isolated in $80.00 \%$ of the oral swab samples. In another study, Vale and Aguiar (2012) isolated Escherichia coli in $41.00 \%$ of the rectal swab samples from captive Callitrichid primates from the National Primate Center. Although this microorganism is part of the normal microbiota of the gastrointestinal tract of warmblooded animals, it is the main cause of urinary tract infections and responsible for hospital infections, including sepsis and meningitis. Its presence in food, water, soil, solutions, and instruments indicate fecal contamination of those sources (JORGE, 2012). Primates feed on fruits, small rodents, and insects, and have the constant habit of putting their dirty and possibly fecal-contaminated hands in their mouth (ASPIS, 2003), a behavior that can justify the high rate of Escherichia coli found in the researched subjects.

In this study, Escherichia coli (71.44\%), Erwinia herbicola (14.28\%), and Kluyvera species (14.28\%) were detected in oral and rectal swabs of seven individuals $(63.33 \%)$. This can be explained by the grooming habits of primates, which is a natural behavior involving the cleaning of different body surfaces. Its primary function is hygiene, but it can also be equally important as a social display behavior, and these animals spend most of their time in grooming activities (HUTCHINS; BARASH, 1976; STAMMBACH KUMMER, 1982; SCHINO, 1988; SUSSMAN et al., 2005). This behavior can be displayed on themselves (self-grooming) or on others in their group (allogrooming). Therefore, it is possible that the researched animals had oral $\times$ rectal or rectal $\times$ oral self-cross-contaminations, or bacterial transmission during allogrooming, resulting in the same bacterial species being detected in both oral and rectal swabs (HUTCHINS; BARASH, 1976).

The second most prevalent microorganisms were Kluyvera species, detected in $20.69 \%$ of the oral and rectal swab samples. Andrade et al. (2010) detected different microorganisms, including Kluyvera species, in primates of the species Macaca fascicularis at the Center for Laboratory Animal Breeding (CECAL/FIOCRUZ), in Rio de Janeiro (RJ). These bacteria are part of the normal human digestive tract microbiota and can be found in the environment as free-living organisms in water, soil, sewage, hospital sinks, and food products of animal origin (POSSUELO; RENNER 2016). Our results demonstrate that humans and primates are sharing susceptibility to different pathogens that can cross interspecific barriers (JOSLIN, 2003), most likely caused by inadequate sanitary management (CYSNE, 2007) in the studied area.

Microorganisms of the genus Enterobacter (E. aerogenes and E. cloacae) are classified as opportunistic (QUINN et al., 2005). These bacteria 
were already detected by Loureiro et al. (1985) and Ramalho et al. (2015) in captive Sapajus apella and Sapajus flavius primates, respectively, their presence being possibly due to the hygiene and social habits of the animals.

Serratia rubidaea is detected mainly in humans with severe trauma or underlying diseases, including sepsis, bacteremia, and urinary tract infections (BONNIN et al., 2015), but it has also been found in black-lion-tamarins in Rio de Janeiro (CARVALHO et al., 2014).

The other enterobacteria isolated in this study (Edwardsiella tarda, Hafnia alvei, Erwinia herbicola, and Pragia fontium) are not commonly related to the normal microbiota of Sapajus nigritus. However, the appearance of these species in the researched animals can possibly be related to park visitors feeding them foods that are not part of their natural diets. This factor may have contributed to the appearance of metabolic and nutritional diseases in local wildlife animals, such as diabetes, obesity, and caries, indicating changes in the microbiota as a possible cause (OLIVEIRA et al., 2015).

Another concern related to microorganisms is bites that visitors can sustain while feeding the primates. These lesions may be the gateway to infections caused by microorganisms found in the oral microbiota of these animals. As there are few studies on this microbiota, they are suspected to carry antimicrobial-resistant bacteria, which would result in serious economic and social consequences to humans.

\section{Conclusions}

The results indicate that the isolated bacteria belong mostly to the human microbiota and that they can cross the interspecific barrier and contaminate nonhuman primates. These primates have hygiene habits that facilitate their interaction with bacteria from the environment and from their excreta, contaminating their oral cavity with fecal and environmental residues.
Environmental education measures should be implemented for the park visitors and the local population who live near the area, such as advising visitors to not feed the animals, keeping garbage containers closed, avoiding closer contact with these animals, and, most importantly, keeping these animals from having contact with human residues. Future studies would be needed to elucidate the possible bacterial contamination among different animal species, humans, and the environment, to propose more effective strategies for human and environmental health preservation.

\section{Ethical Aspects}

This project was approved by the Committee for Ethics in Animal Research (CEPEEA) of the Universidade Paranaense (UNIPAR) under protocol number 28437, and by the Chico Mendes Institute for Biodiversity Conservation (ICMbio) under protocol number 44345-1.

\section{Acknowledgments}

We thank the Coordination for the Improvement of Higher Education Personnel (CAPES) for the PROSUP, and UNIPAR for the funding granted to this research.

\section{References}

ANDRADE, A.; ANDRADE, M. C. R.; MARINHO, A. M.; FERREIRA FILHO, J. Biologia, Manejo e Medicina de Primatas não humanos na pesquisa biomédica. Rio de Janeiro: SciELO-Editora FIOCRUZ, 2010. 471 p.

ASPIS, D.; BALDASSI, L.; GERMANO, P. M. L.; FEDULLO, J. D. L.; PASSOS, E. D. C.; GONÇALVES, M. D. A. Suscetibilidade in vitro a antibióticos de cepas de Staphylococcus spp. e Micrococcus spp. isoladas a partir de mucosa oral de macacos-pregos (Cebus apella) mantidos em cativeiro. Brazilian Journal of Veterinary Research and Animal Science, São Paulo, v. 40, n. 2, p. 83-89, 2003.

BERNARDO, C. S. S.; GALETTI, M. Densidade e tamanho populacional de primatas em um fragmento florestal no sudeste do Brasil. Revista Brasileira de 
Zoologia, Curitiba, v. 21, n. 4, p. 827-832, 2004.

BONNIN, R. A.; GIRLICH, D.; IMANCI, D.; DORTET, L.; NAAS T. Draft Genome Sequence of the Serratia rubidaea CIP 103234T v Reference Strain, a HumanOpportunistic Pathogen. Genome Announcements, Chicago, v. 3, n. 6, p. 1-2, 2015.

BRITO, F. M. M.; ROSA, M. A.; VIEIRA, L. G.; BOSSO, A. C. S.; PEREIRA, H. C.; RIBEIRO, S. C. A.; SANTOS, A. L. Q. Levantamento de flora aeróbica de ânus de primatas do zoológico do Parque do Sabiá, Uberlândia-MG. Veterinária Notícias, Uberlândia, v. 12, n. 2, p. 104-108, 2014.

CARVALHO, V. M.; VANSTREELS, R. E.; PAULA, C. D.; KOLESNIKOVAS, C. K.; RAMOS, M. C. C.; COUTINHO, S. D.; MARTINS, C.; PISSINATTI, A.; DIAS, J. L. C. Nasal, oral and rectal microbiota of Black lion tamarins (Leontopithecus chrysopygus). Brazilian Journal of Microbiology, Rio de Janeiro, v. 45, n. 4, p. 1531-1539, 2014.

CHIARELlO, A. G. Primates of Brazilian Atlantic Forest: the influence of forest fragmentation on survival. Primates in fragments: ecology and conservation. In: MARSH, L. K. Primates in fragments: ecology and conservation. New York: Kluwer Academic e Plenum Publishers, 2003. p. 99-118.

CORTE, A. C.; ITANO, E. N.; ONO, M. A.; MALANSKI, L. D. S.; SHIOZAWA, M. M.; SVOBODA, W; PASSOS, F. Paracoccidioidomycosis-infection in free-living monkeys of northwest Paraná State, Brazil. Revista Instituto de Medicina Tropical de São Paulo, São Paulo, v. 47, n. 14, p. 62-66, 2005.

CRUZ, P. B.; SANTOS, F. N.; ESTEVES, W. T.; ABRANTES, J. A.; CYSNE, L. B.; PINTO, A. C.; NOGUEIRA, J. M. Pesquisa de microbiota normal e de bactérias potencialmente patogênicas em material fecal de primatas não humanos da espécie Macaca fascicularis de cativeiro. Revista da Sociedade Brasileira de Ciência em Animais de Laboratório, São Paulo, v. 4, n. 2, p. 147148, 2017.

CYSNE, B. Análise comparativa do perfil clínico, hematológico e microbiota intestinal associados com quadros diarreicos e não diarreicos de macacos cynomolgus, macaca fascicularis) cativos, 2007. Dissertação (Mestrado em Mestrado em Pesquisa Clinica em Doenças Infecciosas) - Instituto de Pesquisa Clínica Evandro Chagas. Fundação Oswaldo Cruz, Rio de Janeiro.

DASZAK, P.; TABOR, G. M.; KILPATRICK, A.; EPSTEIN, J. O. N.; PLOWRIGHT, R. Conservation medicine and a new agenda for emerging diseases.
Annals of the New York Academy of Sciences, New York, v. 1026, n. 1, p. 1-11, 2004.

DORTU, J. Ulcère de jambe par morsure de singe. Bethesda, Phlebologie, Paris, v. 31, n. 2, p. 113-117, 1978.

GANZHORN, J. U.; LANGRAND, O.; WRIGHT, P. C.; O'CONNOR, S.; RAKOTOSAMIMANANA, B.; FEISTNER, A. T. C.; RUMPLER, Y. The state of lemur conservation in Madagascar. Primate Conservation, Washington, v. 17, n. 1, p. 70-86, 1996.

GARCIA, J. L.; SVOBODA, W. K.; CHRYSSAFIDIS, A. L.; MALANSKI, L. S.; SHIOZAWA, M. M.; AGUIAR, L. M.; NAVARRO, I. T. Sero-epidemiological survey for toxoplasmosis in wild New World monkeys (Cebus spp.; Alouatta caraya) at the Parana river basin, Parana State, Brazil. Veterinary Parasitology, Amsterdam, v. 133, n. 4, p. 307-311, 2005.

GOMES, C. M. B.; SILVA B. K.; OLIVEIRA, S. A.; BEZERRA, L. M. Determinação de enterobactérias de mamíferos silvestres em criadouro conservacionista. Revista de Biologia e Ciências da Terra, Sergipe, v. 11, n. 2, p. 74-80, 2011.

HUTCHINS, M.; BARASH, D. P. Grooming in primates: implications for its utilitarian function. Primates, Quioto, v. 17 , n. 2, p. 145-150, 1976.

JARDIM, M. M. A. Ecologia populacional de bugiosruivos (Alouatta guariba) nos municipios de Porto Alegre e Viamão, RS, Brasil. 2005. (Tese de Doutorado) - Universidade Estadual de Campinas, Campinas.

JORGE, A. O. C. Microbiologia e imunologia oral. Rio de Janeiro: Elsevier, 2012. 369 p.

JOSLIN, J. O. Other primates excluding great apes. In: FOWLER, M. E.; MILLER, R. E. Zoo and wild animal medicine. 5. ed. St. Louis: Saunders, 2003. p. 346-381.

LIMA, D. C. V.; SIQUEIRA, D. B.; APARECIDO, R. Microbiologia de swabs retais e otológicos em carnívoros silvestres do zoológico do Parque Estadual de Dois Irmãos, Pernambuco. Pesquisa Veterinária Brasileira, Rio de Janeiro, v. 32, n. 2, p. 159-164, 2012.

LOUREIRO, E. C. B.; MUNIZ, J. A. P. C.; KINGSTON, W. R. Enterobactérias detectadas em primatas capturados na região amazônica do Brasil. Revista da Fundação SESP, Rio de Janeiro, v. 30, n. 2, p. 121-6, 1985.

LUDWIG, G.; AGUIAR, L.M.; ROCHA, V. J. Comportamento de obtenção de Manihot esculenta Crantz (Euphorbiaceae), mandioca por Cebus nigritus (Goldfuss) (Primate, Cebidae) como uma adaptação alimentar em períodos de escassez. Revista Brasileira de Zoologia, Curitiba, v. 23, n. 3, p. 888-890, 2006. 
LYNCH-ALFARO， J. W. L.; MATTHEWS， L.; BOYETTE, A. H.; MACFARLAN, S. J.; PHILLIPS, K. A.; FALOTICO, T.; MELIN Anointing variation across wild capuchin populations: a review of material preferences, bout frequency and anointing sociality in Cebus and Sapajus. American Journal of Primatology, New York, v. 74, n. 4, p. 299-314, 2012.

MARÓSTICA, L. M. F. Gestão ambiental municipal sustentável. Maringá: Ed. Clichetec, 2010.

MURRAY, P.; ROSENTHAL, K. S.; PFALLER, M. A. Microbiología médica. 7. ed. Rio de Janeiro: Elsevier, 2014. $875 \mathrm{p}$.

NUNES, O. C; OLIVEIRA, E. D.; LABORDA, S. S.; HOHLENWERGER, J. C.; MORAES NETO, M.; FRANKE, R. C. Isolamento e identificação de Salmonella sp. de Jabutis piranga (Chelonoidis carbonaria) oriundos do tráfico de Animais silvestres. Ciência Animal Brasileira, Goiás, v. 11, n. 1, p. 168-173, 2010.

OLIVEIRA, C. N. D. S.; FUSETTI, L. G.; ASSIS, M. B.; BRAGA, R. J.; RIBEIRO, A. R.; MARIANO, M. T. Percepção dos turistas que frequentam o município de poços de caldas quanto à alimentação dos animais silvestres locais. In: CONGRESSO NACIONAL DE MEIOAMBIENTE DE POÇOS DE CALDAS, 12., Minas Gerais, 2015. Anais... Minas Gerais: IFSULDEMINAS, 2015. p. 1-5.

PACHALY, J. R.; CARNEIRO, M. R.; ALBERTON, L. R.; BELETTINI, S. T.; AZZOLINI, F.; PRAZERES, R. F.; VOLTARELLI-PACHALY, E. M. Contenção farmacológica e anestesia de campo em primatas da subfamília Cercopithecinae empregando a fórmula Zax50 (Zoletil/50 + atropina + xilazina). MEDVEP. Revista Científica de Medicina Veterinária. Pequenos Animais e Animais de Estimação, Curitiba, v. 9, n. 30, p. 451-459, 2011.

PINHEIRO, L. C. R.; RODRIGUES, M. C. Potencial zoonótico da microbiota oral e prevalência de lesões orais em macacos-prego (Cebus Libidinosus) mantidos no parque zoobotânico de Teresina. In: SEMINÁRIO DE INICIAÇÃO CIENTÍFICA, 23., Teresina, 2014. Anais... Teresina: Universidade Federal do Piauí, 2014. p. 1-2.

POSSUELO, L. G.; RENNER, J. D. P. Caracterização e identificação microbiológica de Kruyvera sp. e Pantoea sp. Journal of Infection Control, London, v. 4, n. 2, p. $1-2,2016$.

QUINN, P. J.; MARKEY, B. K.; CATER, M. E.; DONNELY, W. J.; LEONAR, F. C. Microbiologia veterinária e doenças infecciosas. Porto Alegre: Artmed, 2005. $512 \mathrm{p}$.
RAMALHO, C. A.; GUIMARÃES, R. A. A.; CAVALCANTE, T. A.; STIPP, D. T.; GUERRA, R. R. Identiicação de enterobactérias em macacos-pregogalego (Sapajus lavius) mantidos em cativeiro no estado da Paraíba. Biotemas, São Carlos, v. 28, n. 3, p. 177-180, 2015.

ROCHA, V. J. Macaco-prego, como controlar esta nova praga florestal. Floresta, Curitiba, v. 30, n. 1-2, p. 95-99, 2000.

SATTERFIELD, W. C.; VOSS, W. R. Nonhuman primates and the practitioner. Veterinary Clinics of North America Small Animal Practice, Philadelphia, v. 17, n. 5, p. 1185-1203, 1987.

SCHINO, G.; SCUCCHI, S.; MAESTRIPIERI, D.; TURILLAZZI, P. G. Allogrooming as a tension-reduction mechanism: a behavioral approach. American Journal of Primatology, New York, v. 16, n. 1, p. 43-50, 1988.

SILVA, E. F. A.; BARROS, J. F. S.; FRAGA, K. B.; MAGALHÃES, C. P.; GARCIA, J. E.; CAVALCANTI, I. M. F. Enterobactérias isoladas da cloaca de Gaviõescarijós (Rupornis magnirostris, GMELIN, 1788) cativos e seu perfil de susceptibilidade a antimicrobianos. Brazilian Journal of Veterinary Research and Animal Science, São Paulo, v. 53, n. 2, p. 207-213, 2016.

STAMMBACH, E.; KUMMER, H. Individual contributions to a dyadic interaction: an analysis of baboon grooming. Animal Behaviour, New York, v. 30, n. 4, p. 964-971, 1982.

SUSSMAN, R. W.; GARBER, P. A.; CHEVERUD, J. M. Importance of cooperation and affiliation in the evolution of primate sociality. American Journal of Physical Anthropology, Hoboken, v. 128, n. 1, p. 84-97, 2005.

VALE, M. C. B.; AGUIAR, D. C. F. Avaliação da microbiota da cavidade oral e anal em famílias de primatas calitriquídeos mantidos em cativeiro. In: SEMINÁRIO DE INICIAÇÃO CIENTÍFICA DA UFPA, 23., Pará, 2012, Anais... Pará: Unversidade Federal do Pará, 2012.p. 1-2.

VAN BELLE, S. E. A. Características demográficas dos Alouatta Pigra populações extensas florestas e fragmentados. In: ESTRADA, A.; GARBER, P. A.; PAVELKA, M. S. M.; LUECKE, L. (Ed.). Novas perspectivas no estudo de primatas mesoamericanos. New York: Springer, 2006. p. 121-142.

VILANOVA, R.; SILVA, J. S.; GRELLE, C. E. V.; MARROIG, G.; CERQUEIRA, R. Limites climáticos e vegetacionais das distribuições de Cebus nigritus e Cebus robustus (Cebinae, Platyrrhini). Neotropical Primates, Washington, v. 13, n. 1, p. 14-19, 2005. 
